\title{
Justice in climate change adaptation planning: conceptual perspectives on emergent praxis
}

\author{
Hartmut Fünfgeld and Benedikt Schmid \\ Institute of Environmental Social Sciences and Geography, University Freiburg, \\ Schreiberstraße 20, 79098 Freiburg, Germany \\ Correspondence: Hartmut Fünfgeld (hartmut.fuenfgeld@geographie.uni-freiburg.de)
}

Received: 3 January 2020 - Revised: 16 September 2020 - Accepted: 5 October 2020 - Published: 16 December 2020

\begin{abstract}
The measures implemented to adapt to climate change are primarily designed to address the tangible, biophysical impacts of climate change in a given geographic area. They rarely consider the wider social implications of climate change, nor the politics of adaptation planning and its outcomes. Given the necessity of significant investment in adaptation over years to come, adaptation planning and implementation will need to place greater concern on justice-sensitive approaches to avoid exacerbating existing vulnerabilities and creating maladaptive and conflicting outcomes. Building on recent calls for more just and transformative adaptation planning, this paper offers a flexible analytical framework for integrating theories of justice and transformation into research on climate change adaptation. We discuss adaptation planning as an inherently normative and political process linked to issues pertaining to recognition justice as well as distributional and procedural aspects of justice. The paper aims to contribute to the growing discussion on just adaptation by intersecting theoretical justice dimensions with spatial, temporal and socio-political challenges and choices that arise as part of adaptation planning processes. A focus on justice-sensitive adaptation planning not only provides opportunities for examining spatial as well as temporal justice issues in relation to planning and decision-making processes. It also paves the way for a more critical approach to adaptation planning that acknowledges the need for institutional restructuring and offers steps towards alternative futures under climate change conditions.
\end{abstract}

\section{Introduction}

Developing a better understanding of the justice implications of adaptation planning and decision-making is becoming a pressing ethical responsibility. Efforts to finance and advance adaptation are ramped up with a sense of urgency across geographic and administrative scales, backed by international funding mechanisms such as the Green Climate Fund under the United Nations Framework Convention on Climate Change (UNFCCC) and the United Nations Adaptation Fund. Since its creation under the Kyoto Protocol in 2008, the latter has received a total of USD 875 million in contributions, of which USD 605 has been committed to adaptation projects and initiatives in the Global South (World Bank, 2019). The Green Climate Fund, which since 2010 has been funding both mitigation and adaptation projects, has committed a total of USD 5.6 billion, of which $24 \%$ have gone towards projects exclusively aimed at adaptation
(Green Climate Fund, 2019). In light of the scale and diversity of these - and myriads of other - forms of public and private investment, it is impossible to ignore that adaptation has become big business. As such, it still is an emerging and highly heterogenous arena of policy-making and practical implementation where, frequently, contested interests are at stake that warrant closer examination. With this in mind, it is pivotal to bring out the political nature of adaptation processes, where much is at stake for those threatened by climate change risks and those experiencing positive and negative outcomes of adaptation efforts. Furthering the research agenda on the role of values, power, justice and the political dimensions of adaptation initiatives and processes is thus an important task for geography and other social sciences to engage in (see for example Glover and Granberg, 2020; Klepp and Chavez-Rodriguez, 2018) and also a central aim of this paper. 
Primarily, adaptation to climate change aims at solving two fundamental problems in a world impacted by the anthropogenic climate crisis. Firstly, adaptation is concerned with functional questions of how desirable futures for humans and non-humans can be realized and safeguarded in spite of the known and yet unknown impacts of climate change. Such functional aspects include, for example, questions of how coastal protection infrastructure can ensure that human and other forms of life in coastal areas prone to inundation and erosion can continue into the future; how human behaviours can be influenced to avoid increasing heat stress among vulnerable population groups in urban areas; and how critical functions of socio-ecological systems can be supported to withstand a rapidly changing climate. In recent years, scholars have developed typologies of climate change adaptation at the local scale that include categories such as capacity building, practice and behaviour, or financing (Araos et al., 2016; Biagini et al., 2014). These have helped structure our understanding of the functional dimensions of adaptation and its planning and practical implementation.

Secondly, adaptation entails normative questions regarding which life forms (and which ways of life) will be enabled or supported to persist in a future under climate change. Tied to this is the question of how well these futures will work out, and for whom (Smit et al., 2000). To put it more bluntly, adaptation is making decisions about which degrees of suffering will be considered acceptable or tolerable, for whose futures, and which futures will be allowed to degenerate or become impossible altogether. In recent years, such notions of the functional as well as the normative boundaries of adaptation have been debated in the context of examining narratives about desirable futures (Bai et al., 2016; Coulter et al., 2019), of loss and damage (Boyd et al., 2017; Huq et al., 2013; Roberts and Pelling, 2019), of the limits of adaptation (Dow et al., 2013; McNamara et al., 2017), and also of a growing interest in the political nature of adaptation in general (Eriksen et al., 2015; Glover and Granberg, 2020; Nightingale, 2017; Webber, 2016).

Such functional and normative questions about plausible and desirable futures (Bai et al., 2016) and future possibilities are the very substance of anticipatory decision-making: adaptation seen from a planning perspective requires deciding between different alternatives and making policy choices that are likely to result in intended outcomes. Planned adaptation can be understood as "a deliberate policy decision, based on the awareness that conditions have changed or are about to change and that action is required to return to, maintain, or achieve a desired state" (IPCC, 2014:869). This deliberate core of adaptation decision-making challenges researchers and practitioners to examine political questions of adaptation justice, such as concern for who participates in decisionmaking, who or what may suffer as a result of adaptation decisions, or who or what may otherwise be negatively affected or excluded from enjoying the benefits arising from current or future adaptation. As adaptation efforts themselves are inherently political - not least by increasingly involving reference to standardized approaches such as institutionbuilding (Nightingale, 2017) - the question that is begging to be asked is to what extent adaptation itself increases or decreases the chances of existing and emergent forms of (injustice. It is evident that adaptation can, for example, cement existing forms of spatial inequality, e.g. by investing limited public funds disproportionately into adaptation measures in areas of high economic value or political interest, while neglecting peripheral areas or marginalized people (see Pelling, 2011; Pelling et al., 2012). Adaptation planning processes can also distort existing and create new forms of vulnerability, with profound discursive and material implications (Farbotko, 2005; Webber, 2013). It is thus timely that in recent years, calls have gained traction for adaptation planning and decision-making to have greater regard for justice and equity issues (Pelling and Garschagen, 2019; Shi et al., 2016).

A focus on justice not only renders visible cases of deepened socio-spatial disparities through (mal)adaptation, but also the structural injustices these are bound up with. Increasingly high levels of socio-economic disparities (Hickel, 2017), un- and post-democratic tendencies (Brown, 2015; Swyngedouw, 2011), and the discursive marginalization of disadvantaged individuals and communities (Spivak, 1988) evidence the uneven institutional arrangements adaptation measures are embedded in.

Adaptation planning, thereby, is inevitably more than a structurally passive response to climate change impacts and risks. Instead, it has to be thought of dialectically: aside from adjusting to climate change, adaptation measures always have an effect on future challenges and capacities (including the reproduction of existing inequalities). Against this background, adaptation has to be as much about "changing social relations and addressing historical injustices and contextual factors that surface as "climate change vulnerability" (O'Brien, 2012:4) as it needs to facilitate adjustment to actual or expected changes.

This paper builds on critical adaptation research that has pushed adaptation planning into a more reflexive and transformative direction (in particular Shi et al., 2016). The aim and contribution of this paper is threefold: first, to link the burgeoning yet often detached debates on adaptation planning, (environmental) justice and socio-ecological transformation; second, to offer a pathway for integrating theories of justice with adaptation planning by acknowledging the temporal, spatial and socio-political dimensions of planning practice and linking these to different moments of justice; and third, to integrate justice perspectives with an explicitly transformative approach to adaptation planning, which remains underdeveloped in adaptation research.

The paper proceeds as follows. Section 2 discusses adaptation planning as an emergent, spatial and temporal praxis that is inherently normative. We draw on existing scholarly discussions to underscore adaptation planning as a social and 
political process with direct bearing on justice outcomes. Based on this, Sect. 3 develops a theoretical perspective on justice-sensitive adaptation planning, as a way of contributing to critical geographic research of adaptation planning processes and to provide a conceptual impetus for promoting a justice-sensitive adaptation planning praxis. Section 4 , then, discusses the consequences for transformative adaptation planning, drawing on examples. The paper concludes with a call for a more comprehensive integration of justice into theories and practices of adaptation planning.

\section{Spatial, temporal and socio-political dimensions of adaptation planning}

Inevitably, adaptation planning is infused with positivist notions of predicting the impacts of climate change and making decisions in accordance with such predictions (typically based on global climate modelling projections). In the absence of full certainty, such planning involves "robust" adaptation decisions that can incorporate future knowledge gains while also raising questions about how much information is sufficient to make such decisions in the present (Dessai and Hulme, 2007; Lempert and Schlesinger, 2001; Wilby and Dessai, 2010). Scholars in geography and the environmental social sciences have highlighted the risks of deterministic thinking about climate change adaptation (e.g. Head, 2010) and pointed to the social and cultural construction and hence political and contested nature of adaptation (Adger et al., 2012; Hulme, 2009), which continue to resonate with scholarly debates in human geography (see for example Bulkeley, 2019; Lovell, 2019).

In order to examine the justice implications of adapting to climate change, we explicitly refer to adaptation planning, rather than planned adaptation or adaptation, as a way of focusing in on the process-related and at the same time normative character of individuals and groups actively engaging in making deliberate, spatially and temporally contextualized decisions. This emphasis is to highlight that adaptation is about substance as well as about process: the substantive need for adaptation planning arises from the global climate crisis and its future socio-ecological ramifications as increasingly material climate change impacts threaten ever more aspects of human and non-human life. Addressing this substantial need, however, requires a continuous process of adapting, i.e. continuous planning and decision-making in a context of emergent complexity. At the core of climate change adaptation, thus, is an emergent and evolving praxis of planning that requires making many inherently normative decisions about a future in which taken-for-granted environmental, social and economic parameters will (and have to be) substantially altered.

Engaging in adaptation therefore requires clarification of the normative goals of the process. Here, the distinction between incremental and transformational adaptation comes into play. According to the IPCC, incremental adaptation has as the central aim "to maintain the essence and integrity of a system or process at a given scale" (IPCC, 2014:1758). Actions arising from incremental planning are geared towards reducing sensitivity, changing exposure, or increasing the adaptive capacity of individuals or groups (Park et al., 2012). Adaptation planning understood in an incremental way is therefore inherently conservative: it primarily serves to maintain a system's functioning in its current state or form in the face of climate change impacts. Transformational adaptation, on the other hand, has been defined by the IPCC as "adaptation that changes the fundamental attributes of a system in response to climate and its effects" (IPCC, 2014:1758). Different conceptualizations of transformation, however, disagree on the system perspective, on the boundaries of the system in question, and on the extent to which the changes to system attributes are emergent or deliberate (Feola, 2015). Critical social science authors have highlighted the role of deliberate choices in supporting transformational adaptation that engenders positive innovation and non-linear outcomes (O'Brien, 2012; O'Brien and Barnett, 2013; Patterson et al., 2018; Tschakert et al., 2013). Adaptation planning, as conceptualized here, is thus inextricably confronted with the progressive potential offered by transformation (Pelling, 2011; Pelling et al., 2014), while also acknowledging that its efforts can lead to both positive and negative outcomes (Park et al., 2012).

Explicitly linking adaptation to transformation has a twofold conceptual advantage. First, such a perspective underlines the dynamic, process-related character of the socioecological relations that adaptation planning is concerned with and simultaneously a part of. And second, this perspective portrays the dynamics of socio-ecological relations as inherently political, raising questions of directionality, normativity, agency, power, and the justice of adaptation processes and outcomes. Before taking adaptation planning into a more proactively change-oriented direction - an aspiration we formulate and detail below - this section explores the challenges and choices inherent in adaptation planning practice. A broad-brush distinction between temporal, spatial and socio-political dimensions of adaptation planning, thereby, helps to outline its contested and normative nature. This categorization, of course, can only be an analytical one, as all three dimensions are mutually constitutive, rendering adaptation planning a diverse and heterogenous praxis.

\subsection{Temporal challenges}

Mitigation policies focus on avoiding additional future climate change and ensuring that planet Earth remains inhabitable for future generations of humans, plants and animals. Adaptation planning, as outlined here, is about addressing the future risks of climate change through deliberate action (Shi et al., 2016). It is based on the premise of making efforts now (i.e. using financial resources, political capital, etc.) to 
ensure that future living conditions under the impacts of climate change are as bearable as possible and that unnecessary harm is avoided. In a temporal perspective, a key argument for distinguishing adaptation planning from adaptation per se is to emphasize that the former is always of anticipatory quality, concerned with shaping a future constrained by inevitable climate change. Unlike the term adaptation, adaptation planning always infers human agency, i.e. deliberate acts of individuals or groups afforded with the power to make decisions in order to avoid harm, for themselves or to others, and, as discussed below, with significant justice implications (Eriksen et al., 2015; Nightingale, 2017). Such agency changes over time, alongside changing knowledge, changing societal recognition of the need for adaptation and dynamic political processes associated with these changes.

\subsection{Spatial challenges}

With regard to the spatial dimension, the argument has often been made that local-scale decision-makers are best placed to conduct adaptation planning and implement adaptation actions (Bours et al., 2015; Corfee-Morlot et al., 2011; Satterthwaite et al., 2009), a "scientific mantra" that has been questioned in light of the realities of limited local capacity, shared responsibility for adaptation across scales and institutions, and interactions between local actors and those operating at other scales of global risk governance (Nalau et al., 2015). Uncertainties regarding the spatially differentiated effects of climate change impacts, in particular of sudden, rapid-onset extreme events, constitute a fundamental challenge for adaptation planners and decision-makers. The arbitrariness and unpredictability of, for example, extreme precipitation events call for systemic adaptation that is not targeting individual sites or areas but aims at reducing vulnerabilities across the system, e.g. by increasing retention capacity across entire catchments. Adaptation planning, though creating largely localized benefits, is also imbued with multi-scale entanglements of material biophysical impacts - themselves effects of globally interlinked processes - and the multi-level political, social and institutional structures and processes that facilitate, enable or constrain adaptation planning in localized contexts (Eriksen et al., 2015; Nightingale, 2017). Nevertheless, adaptation planning is highly place-specific and has to be attentive to local community preferences, their value systems and to locally embedded modes of governance. A spatial perspective on adaptation planning can render territorial (e.g. laws and regulations), place-based (e.g. local struggles), scalar (e.g. multi-level governance) and network (e.g. translocal cooperation) dimensions visible.

\subsection{Socio-political challenges}

Practical limitations - most notably limitations pertaining to the financial resources available for adaptation - make adaptation an ongoing process during which value-based, often contentious decisions are made about who or what to protect and at what cost (Smit et al., 2000). Such decisions are never value neutral but involve different interests, material and discursive resources, and potentially conflicting lifestyles, value systems and frames of reference. Adaptation planning, therefore, always has to be viewed against the background of the power relations that are involved and reproduced, the ways of live that are privileged, and the voices that are being heard (Chu et al., 2016; Morchain, 2018; Nightingale, 2017).

These temporal, spatial and socio-political dimensions present those involved in adaptation planning with deliberate, yet difficult choices (Table 1): decisions need to be made about when adaptation planning is triggered and on what grounds; which time frames adaptation planning and concrete measures should encompass; where planning efforts are to be focused; and for the protection or support of whom or what these are intended. Fundamental and constitutive is the socio-political question of who should be in charge of, and involved in, a given adaptation planning process.

Decisions about the scope of adaptation planning are likely to be contested, as potential trade-offs need to be identified, understood and weighed up. The inherently social and political dimensions of such decision-making under uncertainty, with spatially and temporally differentiated processes and outcomes, appear impossible to ignore. Despite this, many practical examples of adaptation planning remain focused on devising and implementing engineering and environmental measures (Pelling and Garschagen, 2019) and on forms of institutional development that continue to neglect power relations and the political and social dimensions of adaptation at large (Nightingale, 2017).

The challenges of adaptation planning as outlined here highlight a fundamental characteristic that is lost in common definitions of adaptation as a "process of adjustment to actual or expected climate and its effects" that "seeks to moderate or avoid harm or exploit beneficial opportunities" (IPCC, 2014:1758): that adaptation to climate change inevitably raises multidimensional questions of justice. Inflecting the IPCC's definition that is grounded in positivist science, adaptation planning seen through a justice lens, grounded in a socially constructivist ontology, is thus perhaps best described as the political process of humans making deliberate choices in order to avoid harm or exploit beneficial opportunities and adjust to and transform the socio-political entanglements for themselves or for non-human life forms. In the academic literature to date, such concerns about the complex rationales of adaptation planning decisions have been examined in the context of value-based approaches to adaptation (Granderson, 2018; O'Brien and Wolf, 2010), by conceptualizing different forms of maladaptation (Barnett and O'Neill, 2010; Juhola et al., 2016; Magnan et al., 2016) and by examining what may constitute success in adaptation (Adger et al., 2005; Moser and Boykoff, 2013). Geographers have also discussed hidden political agendas of adaptation as part of critical geographies of adaptation (Goldman et al., 2018; Nightin- 
Table 1. Spatial, temporal and socio-political challenges of climate change risks and ensuing basic choices in adaptation planning.

\begin{tabular}{|c|c|c|c|}
\hline Risks of climate change & Temporal challenges & Spatial challenges & Socio-political challenges \\
\hline $\begin{array}{ll} & \text { Biophysical impacts } \\
\text { - } & \text { Ecological, economic, } \\
\text { and social effects } \\
\text { - }\end{array}$ & $\begin{array}{l}\text { - Temporal } \\
\text { uncertainties of } \\
\text { current and future } \\
\text { impacts } \\
\text { - Complexities of } \\
\text { coinciding impacts } \\
\text { and their } \\
\text { compounding effects } \\
\text { - Uncertainties about } \\
\text { mitigation and } \\
\text { adaptation efforts and } \\
\text { outcomes }\end{array}$ & $\begin{array}{l}\text { Spatial uncertainties } \\
\text { regarding location- } \\
\text { specific impacts } \\
\text { Complexity of local- } \\
\text { to-regional scale } \\
\text { impacts } \\
\text { Manifestations of } \\
\text { local-to-global } \\
\text { governance processes }\end{array}$ & $\begin{array}{l}\text { Different groups and } \\
\text { interests involved } \\
\text { Unevenly distributed } \\
\text { material and } \\
\text { discursive } \\
\text { resources/power } \\
\text { Multiple and } \\
\text { potentially conflicting } \\
\text { lifestyles, value } \\
\text { systems, and frames of } \\
\text { reference. }\end{array}$ \\
\hline
\end{tabular}

\begin{tabular}{|c|c|c|c|}
\hline Adaptation planning & Temporal choices & Spatial choices & Socio-political choices \\
\hline Scope & $\begin{array}{l}\text { When to engage in } \\
\text { planning? } \\
\text { Using which planning time } \\
\text { frames? } \\
\text { Who decides on temporal } \\
\text { aspects? }\end{array}$ & $\begin{array}{l}\text { Where to focus planning? } \\
\text { Selecting spatial focus } \\
\text { based on which criteria? } \\
\text { Who decides on spatial } \\
\text { focus? }\end{array}$ & $\begin{array}{l}\text { Which ways of life are } \\
\text { privileged? } \\
\text { Which relations of power } \\
\text { (re)produced? } \\
\text { Which voices are heard? }\end{array}$ \\
\hline Potential trade-offs & $\begin{array}{l}\text { Protecting present vs. } \\
\text { future values / generations }\end{array}$ & $\begin{array}{l}\text { Protecting/supporting } \\
\text { some areas, assets and life } \\
\text { forms while neglecting } \\
\text { others }\end{array}$ & $\begin{array}{l}\text { Protecting existing } \\
\text { relations of power and } \\
\text { value systems vs. } \\
\text { alternative ones }\end{array}$ \\
\hline
\end{tabular}

gale, 2017; Webber, 2016) - and with even greater vigour, resilience (Grove, 2013; MacKinnon and Derickson, 2013). Such critical perspectives on the political dynamics of adaptation are closely intertwined with fundamental questions about justice.

\section{Justice in the context of adaptation planning}

To examine the relationship between adaptation planning and environmental justice considerations, we draw on different strands of justice theory that are prominent in academic discourse. In recent years, a growing scholarship has been concerned with understanding the specific ramifications of climate change on questions of justice and explored environmental justice issues as part of a focus on energy justice and just transition (Jenkins, 2018; Sovacool et al., 2013; McCauley and Heffron, 2018), urban climate justice (Bulkeley et al., 2014; Chu and Michael, 2019; Hughes, 2013; Porter et al., 2020; Steele et al., 2012), and more specifically urban adaptation and resilience (Shi et al., 2016; Ziervogel et al., 2017). In the following, spatial, temporal and socio-political challenges and choices introduced above serve as analytical lenses to help examine the relationship between environmental justice concerns and adaptation planning.

Justice issues with regard to climate change impacts and adaptation arise across multiple spatial and temporal scales. In global spatial terms, a fundamental justice problem is the fact that some of the communities hardest hit by climate change impacts have contributed relatively little to the problem (Dodman and Satterthwaite, 2008). The discourse surrounding foregone futures of small island developing states (SIDS) as a result of climate change epitomizes the existential nature of justice in the face of climate change (Barnett and Campbell, 2010; Betzold, 2015; Farbotko and McMichael, 2019; Weir and Pittock, 2017). Spatial distortions of cause and effect extend from the international to the local scale, where marginalized individuals and groups lack the financial means for participating in capitalist mass consumption. Due to their relative economic deprivation, they lead relatively low-carbon lifestyles, thus contributing, perhaps involuntarily, to limiting greenhouse gas emissions and thus climate change. At the same time, however, these individuals may not only be more exposed to the impacts of climate change but also more sensitive and lacking adaptive capacity, leading to overall increased levels of vulnerability (Dodman and Satterthwaite, 2008). Adaptive capacity is commonly defined as "the ability of systems, institutions, humans, and other organisms to adjust to potential damage, to take advantage of opportunities, or to respond to consequences" (IPCC, 2014:1758). We revisit the challenges with this rather apolitical definition from a justice perspective below.

In temporal terms, present vulnerabilities, needs and capacities influence and are weighted against those of future generations. This does not only pertain to the climatic trajectories, which are shaped through past and present decisions, but also to the social and material resources present and future generations have at their disposal to address con- 
tinuing climatic destabilization. At any point in time, therefore, adaptive capacities are closely bound up with socioeconomic relations that were constituted in the past, linking adaptation to questions of historically evolved relations of power and responsibility.

Acknowledging the reality that climate change is already resulting in a multitude of forms of suffering (Hulme, 2009), concern for justice in adaptation planning thus first and foremost has to untangle how such suffering has been and will be allocated across societies at different spatial and temporal scales. For years, globally comparative analyses and indices of climate change vulnerability, risks of harm from extreme weather, and transnational climate-change-related risks have attempted to do just that (e.g. the ND-GAIN; the Global Climate Risk Index, Eckstein et al, 2020; or the Transnational Climate Impacts Index, Benzie et al., 2016), while vulnerability assessments have downscaled quantitative measurement to national and sub-national scales (Füssel and Klein, 2006; Klein and Nicholls, 1999; Yuen et al., 2012). Such assessments can be particularly important for uncovering existing forms of contextual vulnerability, which are corroborated by the impacts of climate change (van den Berg and Keenan, 2019; O'Brien et al., 2007). They can provide a useful basis for decision-making that is sensitive to justice issues. However, since their approach is predominantly diagnostic, they require subsequent consideration of spatially and temporally differentiated vulnerabilities and matters of scale as part of adaptation planning (Fekete et al., 2010).

To further examine spatial and temporal issues of (in-)justice in adaptation planning, prominent theoretical perspectives offered by environmental justice theory can be applied to shed light on emergent socio-political challenges and choices. Three theorizations regarding distributional, recognition and procedural justice aspects have guided academic and non-academic work on environmental justice (Schlosberg, 2004, 2012; Walker, 2012).

\subsection{Distributive justice}

Adaptation planning is a critical lever for influencing the distribution of climate-change-induced suffering and harm. In particular, the distribution of the benefits of successful adaptive measures - predominantly reduced climate change vulnerability of some kind - will substantially influence the socio-spatial extent as well as the severity of suffering experienced. Therefore, adaptation planning itself - and not merely climate change impacts - results in emergent "goods" and "bads", i.e. in new or altered forms of privilege and hegemony and in dynamics of relative and absolute disadvantage. Such emergent dynamics of privilege and disadvantage can include, for example, decision-makers agreeing to give preference to the construction of coastal infrastructure, built in order to "hold the line" and protect prime real estate coastal properties, while rejecting alternative choices, such as stopping coastal development altogether or planning for a retreat of settlements from coastlines threatened by sea-level rise (Abel et al., 2011; Mycoo, 2018; Niven and Bardsley, 2013). Either of these choices can result in benefits in the form of reduced vulnerability for some, while likely leading to emergent economic costs and injustice for those affected by the changes (see for example Buckley, 2013). Beyond economic dimensions, such adaptation planning decisions will also affect the relevance attributed to cultural dimensions of climate change, such as place attachment and connected, spatially bound feelings of identity and belonging (Adger et al., 2011, 2012; Agyeman et al., 2009).

The goods and bads that can result from adaptation planning can come in many guises. Goods may range from, for example, increased utility gained from better-adapted infrastructure, such as an urban park with plenty of shaded areas, to individual financial gains associated with better adapted flood risk management in residential areas, and to social goods such as increased community cohesion in a neighbourhood as a result of regular wildfire preparedness training exercises to increase adaptive capacity (Every et al., 2016). Where the need to adapt exceeds either the capacity or the political or societal will to adapt, distributive justice will largely be about making normative choices about who or what will be left with the residual bads of climate change impacts, such as negative effects on human health and well-being.

John Rawls' seminal theoretical work on distributive justice emphasizes the allocation of resources across time and space so that they end up providing the greatest benefit to the most disadvantaged groups or individuals in society. A Rawlsian view on justice, then, implies that those most vulnerable to climate change should be the preferred recipients of benefits created by adaptation efforts. Considering the definition of adaptation planning above and relating it to Rawlsian thought, we may thus say that adaptation planning should result in a more equitable distribution of social and environmental goods and bads, for human or non-human entities. Beyond facilitating a more equitable distribution of climatechange-induced suffering, adaptation planning should thus also concern itself with influencing the socio-spatial and temporal distribution of the benefits of increased protection and avoided harm from climate change, in a way that overall contextual vulnerabilities are reduced, now and in the future.

However, as a universal state of "being well-adapted" is an impossibility, the political economy of adaptation planning is likely to distort such idealized notions of justice. Adaptation measures often primarily service individuals and groups with relatively low vulnerability to climate change (Adger, 2006; Paavola and Adger, 2006) and can therefore be considered social maladaptations (Barnett and O'Neill, 2010; Juhola et al., 2016). They redistribute relative vulnerabilities, resulting in increased vulnerability differentials within a system. They can also lead to opportunity costs that prevent a fairer distribution of social goods and bads and exacerbate existing forms of hegemony and privilege. A distributional justice lens on adaptation planning can thus bring to light political 
interests that are at stake when spatial and temporal adaptation planning decisions are made. Ex ante, it can help sharpen local discourse of what idealized distributions of adaptation benefits could look like and diagnose forgone opportunities for un(just) adaptation outcomes ex post.

\subsection{Procedural justice}

Examining adaptation planning simply through a distributive lens provides only a partial perspective on justice issues. Where adaptation planning results in collective social benefits, such as increased social cohesion and the development of support systems at neighbourhood level, reducing adaptation planning to a means for producing more equitable distribution outcomes ignores much of the politics of adaptation processes and their transformative potential.

Sen (2009), by extending his own work on freedoms and drawing on Rawls' work, highlights that in addition to distributional aspects, people need to have the opportunity to take part in decision-making processes. Nussbaum (2002, 2011), drawing on Sen's work in turn, applies a rights-based approach to argue that all people should have at their disposal a minimum set of capabilities that enable them to pursue their life goals. Accordingly, procedural justice with respect to adaptation planning entails in its basic form the need to ensure that people either affected by climate change impacts or by the results of adaptation planning have real opportunities and suitable capabilities for participating in the process of adapting to climate change (see Nussbaum, 2011). Merely providing opportunities for procedural inclusion by having a "seat at the table" (Malloy and Ashcraft, 2020:5), however, represents a distorted and potentially manipulative form of procedural justice that does not afford vulnerable groups political power over decision-making processes (Holland, 2017; Malloy and Ashcraft, 2020).

Adaptation planning has a mixed record when it comes to procedural justice issues. On the one hand, efforts in community-based adaptation have highlighted the benefits (as well as some pitfalls) of inclusive and grassroots-driven planning and decision-making (Ayers and Forsyth, 2009; Reid and Schipper, 2014). Municipal-level adaptation planning, however, has a history of being technocentric and guided by top-down risk assessments and climate modelling (Finn and McCormick, 2011). While community members are frequently included in vulnerability assessments in some manner, they rarely participate in the framing of adaptation goals (Few, 2007). A transformative procedural justice concern therefore pertains to how climate change risks and adaptation objectives are defined and constructed in discourse and through political process. Crucially, adaptation planning sensitive to procedural justice needs to ask who is involved in such problem framing processes and in effectuating tangible outcomes (Forsyth, 2014; Holland, 2017).

\subsection{Recognition justice}

Justice-sensitive adaptation planning ought to acknowledge that historical processes have led to structural exclusion of some parts of society. Materially disadvantaged groups are also marginalized by a structural lack of capacity and opportunity to have a voice and participate in discourses on justice issues (Fraser, 2000, 2001). Structural adaptive capacity can be low due to limited resources and capabilities, even in seemingly high-capacity contexts (Fünfgeld et al., 2019). Consequently, questions of the distributive and procedural justice dimensions of adaptation planning cannot be separated from questions of recognition (Schlosberg, 2004). Injustice is not merely a manifestation of the unfair distribution of goods and bads and a lack of real democratic participation, but rather a result of material and symbolic processes of privilege and oppression that can only be understood in a historical perspective. Recognition aspects of justice, such as degrees of respect afforded to individuals or social groups, greatly influence people's status and thus their ability to be considered as legitimate voices in adaptation planning. Technocentric and technocratic adaptation planning tends to disregard the diversity of livelihoods and human-nature interdependencies. Recognition justice in adaptation planning, therefore, requires the acknowledgement of multiple forms of knowledge and expertise, in particular that of affected groups and communities, including youth and children (Mitchell and Borchard, 2014).

A justice lens on adaptation planning, therefore, requires us to critically examine "how power moves around" (O'Brien and Barnett, 2013:383), thus leading to differentiated outcomes with regard to who or what is included and who participates in the political process of defining such inclusions and exclusions. Table 2 below summarizes key justice implications in relation to the spatial and temporal dimensions of adaptation planning.

\section{Linking justice to emergent adaptation planning praxis}

The discussion of the trivalent justice dimensions has highlighted that the notion of adaptive capacity can be considered a critical conceptual link between adaptation planning and environmental justice considerations, because it relates not only to distributive but also to recognitional and procedural dimensions of justice. In opposition to a rather apolitical framing of adaptive capacity introduced above, we contend along with other scholars that justice considerations need to be placed at the centre of adaptation planning research and practice, by normatively (re-)framing it as an inclusive and multifaceted process for developing adaptive capabilities in individuals, social groups and non-human entities most vulnerable to the impacts of climate change. This underscores the notion of "the politics of climate-as-condition" (Bulkeley, 2019) and explicitly includes the central capability to 
Table 2. Spatio-temporal perspectives on adaptation planning through the lenses of justice theory.

\begin{tabular}{|c|c|c|}
\hline & Spatial dimensions & Temporal dimensions \\
\hline Distributional & $\begin{array}{l}\text { - Geographic distribution of people/species } \\
\text { affected by goods and bads of } \\
\text { climate change } \\
\text { - Socio-spatial differentiations of goods and } \\
\text { bads as a result of adaptation planning }\end{array}$ & $\begin{array}{l}\text { - Intra- and intergenerational distribution of the } \\
\text { goods and bads of climate change } \\
\text { and adaptation } \\
\text { - Historical trajectories of marginalization that } \\
\text { have led to socially unequal distribution of } \\
\text { vulnerabilities }\end{array}$ \\
\hline Procedural & $\begin{array}{l}\text { - Spatially exclusive/inclusive patterns of } \\
\text { access to participation in adaptation } \\
\text { planning, e.g. with regard to urban } \\
\text { academic elites }\end{array}$ & $\begin{array}{l}\text { - Domination of adaptation planning by adult/ } \\
\text { elderly/“expert" individuals not personally } \\
\text { affected by its mid-/long-term outcomes }\end{array}$ \\
\hline Recognition & $\begin{array}{l}\text { - Spatially disparate recognition of social } \\
\text { groups/species to be protected from climate } \\
\text { change impacts } \\
\text { - Recognition of marginalized groups, } \\
\text { including youth and children, as legitimate } \\
\text { voices in adaptation planning }\end{array}$ & $\begin{array}{l}\text { - Recognition of the voices (knowledge, stories, } \\
\text { etc.) of those most affected by climate change } \\
\text { impacts and adaptation } \\
\text { - Historical patterns of geographic hegemony and } \\
\text { exploitation reproduced in adaptation planning } \\
\text { - Recognition of, in particular, youth and children } \\
\text { as legitimate voices in adaptation planning }\end{array}$ \\
\hline
\end{tabular}

Source: Authors, based on Rawls (2005) [1971], Fraser (2000), Sen (2009), Nussbaum (2011) and others cited above.

have shared political control over one's environment (Nussbaum, 2011). Such reconceptualization of adaptive capacity as capabilities shifts the perspective away from physical, social and financial assets or "capital" as determinants of the ability to adapt, towards an actor-orientated, justice-informed perspective of who or what can and should be adapting, when and how. A differentiation of spatial, temporal and sociopolitical challenges and choices, we contend, can support a more nuanced analysis of how adaptive capabilities can be effectively fostered and deployed.

In municipal adaptation planning, working towards justice-sensitive adaptation requires the means for expanding planning efforts from the currently dominant practice of sectoral adaptation planning that is heavily supported by international organizations into the wider societal realm, e.g. by empowering and capacitating community groups and smaller organizations in non-traditional sectors. Rather than thinking of adaptation (solely) passively as adjustment to an external problem, adaptation planning, then, extends towards addressing structural inequalities by building the foundations for developing adaptive capabilities. This in turn means providing resources and spaces for (marginalized) communities to empower themselves and respond to (global) challenges, including but not limited to climate change. This does not preclude decisive top-down measures such as protective infrastructures and the improvement of social services. Transformative and justice-oriented adaptation planning, however, requires these measures to be embedded in, instead of being imposed on, communities.

Equitable and just adaptation planning, in this sense, is explicitly transformative. To borrow a notion from trans- formation research (in particular anarchist-inspired theory), adaptation needs to include a prefigurative politics. Prefiguration, here, means to instigate "examples of the future in the present" (Chatterton, 2016:405). It thus highlights how an "equitable and just future is embodied in, and grows from, the practices of the present" (Schmid and Smith, 2020:8).

Examples for a prefigurative politics in adaptation planning include resilient and community-based food systems or the greening and reappropriation of public city spaces. Community-supported agriculture (CSA) schemes aim, amongst other things, at increasing the food and income security of citizens and farmers. Consumers and producers that are members of a CSA group share the risks as well as the fruits of a good or bad harvest. This becomes increasingly important in face of climate destabilization. By (partially) demarketizing food production, CSA schemes, furthermore, create spaces to experiment with more climate resilient forms of agriculture, often turning to principles of permaculture ("permanent agriculture" - a regenerative and holistic approach to agriculture). In addition, CSA schemes are based on solidarity principles of ability-based contributions that acknowledge socio-economic differences.

A related trend and second example for prefiguration in adaptation planning are urban gardening and edible city projects. Some municipalities have recognized the multiple benefits of urban food production that include greening and shading of city space, the localization of food production, and the fostering of community exchange. The list of urban gardening type of initiatives is long and includes both top-down (e.g. Andernach, Germany; Havanna, Cuba; see Artmann et al., 2020; Säumel et al., 2019) and 
Table 3. Key questions for justice-sensitive adaptation planning.

\begin{tabular}{|c|c|c|c|}
\hline & Functional questions & Normative questions & Transformative questions \\
\hline Distributional & $\begin{array}{l}\text { Who/what can feasibly be } \\
\text { protected? } \\
\text { How can protection from } \\
\text { harm and suffering be } \\
\text { achieved? } \\
\text { How can fair distribution } \\
\text { of adaptation benefits across } \\
\text { space and time be achieved? }\end{array}$ & $\begin{array}{l}\text { Who/what should be protected } \\
\text { from the impacts of climate change? } \\
\text { Who/what should benefit from } \\
\text { limited resources available for } \\
\text { adaptation planning? }\end{array}$ & $\begin{array}{l}\text { How can (material) resources } \\
\text { be channelled towards } \\
\text { structurally disadvantaged } \\
\text { groups? } \\
\text { What relations empower } \\
\text { communities to adapt to local } \\
\text { impacts of climate change? }\end{array}$ \\
\hline Procedural & $\begin{array}{l}\text { How and at what point can } \\
\text { affected people participate } \\
\text { in the process? }\end{array}$ & $\begin{array}{l}\text { Who should be involved in making } \\
\text { decisions as part of adaptation } \\
\text { planning? }\end{array}$ & $\begin{array}{l}\text { How can adaptation planning } \\
\text { contribute to the creation } \\
\text { of more direct-democratic } \\
\text { forms of governance? }\end{array}$ \\
\hline Recognition & $\begin{array}{l}\text { How can marginalized groups } \\
\text { obtain a voice in adaptation } \\
\text { planning? } \\
\text { How can fair representation } \\
\text { of non-participating beings } \\
\text { be ensured? }\end{array}$ & $\begin{array}{l}\text { Who should have a voice in } \\
\text { adaptation planning? } \\
\text { Who is legitimized to speak on } \\
\text { behalf of others (humans and } \\
\text { non-humans) who are not able to } \\
\text { participate in adaptation planning? }\end{array}$ & $\begin{array}{l}\text { How can forms of adaptation } \\
\text { planning support the recognition } \\
\text { of diverse needs and value } \\
\text { systems? }\end{array}$ \\
\hline
\end{tabular}

bottom-up examples. Some cities have taken up the impulse from community-led initiatives and integrated urban gardening into city planning processes (e.g. the City of Geneva, Switzerland; see Nikolaïdou et al., 2016).

In summary, if adaptation planning is to become more sensitive to justice issues, those tasked with designing or initiating policy frameworks for adaptation or adaptation planning processes themselves need to respond to a series of normative as well as more objectively verifiable, functional questions that go well beyond considering climate change as an external problem that requires a set of solutions. Some of these questions are outlined in Table 3 below.

Finding answers to these questions requires full acknowledgement of the political nature of adaptation processes and its potentially unjust processes and outcomes. Due to the structural nature of recognition dimensions of justice, the net has to be cast wider if adaptation planning is to positively affect not only unjust distribution and limited participation opportunities, but also poor recognition and structural lack of adaptive capabilities. In concrete terms, this may mean that justice-sensitive adaptation planning requires developing adaptive capabilities not only of affected individuals but of other parts of the system of interest that are relatively marginalized and deprived of adequate political power to exert control over adaptation processes and outcomes. This may include empowering smaller local governments to engage in adaptation, developing adaptive capabilities in sectors not at the heart of local adaptation (such as health and psycho-social service providers), and working with local community-based organizations to actively demand and use opportunities for engagement in adaptation planning. Lastly, justice-sensitive adaptation planning will also need to devise suitable mechanisms for recognizing the needs of nonhuman entities as part of adaptation planning (see, for example, Steele et al., 2015).

\section{Conclusion}

In this paper, we have maintained a view that examining the spatial, temporal and socio-political ramifications of adaptation planning is a critical precondition for developing more justice-sensitive ways for tackling the impacts of climate change. We have examined the links between adaptation planning, justice considerations and notions of adaptive capabilities. We have argued that adaptation planning needs to be broadened out to become recognized as an emergent praxis that acknowledges the social and political nature of adaptation to climate change in human systems. In a reconfigured adaptation planning praxis that is cognisant of its responsibility towards as-just-as-possible decision-making, supporting the development of adaptive capabilities as a form of recognition is critical for achieving greater procedural and distributive justice. Such normative approaches towards just adaptation planning can benefit from employing a capabilities perspective that recognizes people's ability to not only become the recipients of goods and bads of climate change adaptation, but also their freedom of having a genuine voice in framing adaptation goals and deciding who or what ought to be supported through adaptation. As a crucial step in designing justice-sensitive adaptation planning processes, therefore, we suggest taking a perspective on prefiguration and the key questions for justice-sensitive adap- 
tation planning introduced above as starting-point tools for a truly open-ended deliberation that involves diverse voices from across the spectrum of local and non-local stakeholders. Such preparatory work can set up an adaptation planning trajectory that is pluralistic in its consideration of values, leading to results that are potentially more meaningful and politically grounded.

This overview paper is intended as a contribution for stimulating further discussion on the role of justice considerations in adaptation planning. Further research could substantiate the relevance of justice-informed approaches for justicesensitive adaptation planning in specific institutional situations, facing a variety of climate change risks. Almost by definition, such studies would need to include transdisciplinary research that co-produces knowledge about suitable planning and decision processes and criteria for identifying system boundaries, as well as concrete training and capacitybuilding needs and methods for developing adaptive capabilities.

Data availability. No data sets were used in this article.

Author contributions. HF was responsible for conceptualizing, for writing the original draft and for preparing the tables. BS contributed to the conceptualization and to the writing of the final draft.

Competing interests. The authors declare that they have no conflict of interest.

Acknowledgements. We would like to thank Anna Lena Bercht, as well as Silja Klepp and Jonas Hein, for their editorial support and feedback. Furthermore, we thank participants of the 2019 EnJust Workshop in Kiel, Germany, and two anonymous reviewers for their insightful and constructive comments.

Review statement. This paper was edited by Anna Lena Bercht and reviewed by two anonymous referees.

\section{References}

Abel, N., Gorddard, R., Harman, B., Leitch, A., Langridge, J., Ryan, A., and Heyenga, S.: Sea level rise, coastal development and planned retreat: analytical framework, governance principles and an Australian case study, Environ. Sci. Policy, 14, 279-288, https://doi.org/10.1016/j.envsci.2010.12.002, 2011.

Adger, N. W.: Vulnerability, Global Environ. Change, 16, 268-281, https://doi.org/10.1016/j.gloenvcha.2006.02.006, 2006.

Adger, N. W., Arnell, N. W., and Tompkins, E. L.: Successful adaptation to climate change across scales, Global Environ. Change Pt. A, 15, 77-86, https://doi.org/10.1016/j.gloenvcha.2004.12.005, 2005.
Adger, N. W., Barnett, J., Chapin III, F. S., and Ellemor, H.: This Must Be the Place: Underrepresentation of Identity and Meaning in Climate Change Decision-Making, Global Environ. Polit., 11, 1-25, 2011.

Adger, W. N., Barnett, J., Brown, K., Marshall, N., and O'Brien, K.: Cultural dimensions of climate change impacts and adaptation, Nat. Clim. Change, 3, 112-117, https://doi.org/10.1038/nclimate1666, 2012.

Agyeman, J., Devine-Wright, P., and Prange, J.: Close to the edge, down by the river? Joining up managed retreat and place attachment in a climate changed world, Environ. Plan. A, 41, 509-513, https://doi.org/10.1068/a41301, 2009.

Araos, M., Berrang-Ford, L., Ford, J. D., Austin, S. E., Biesbroek, R., and Lesnikowski, A.: Climate change adaptation planning in large cities: A systematic global assessment, Environ. Sci. Policy, 66, 375-382, https://doi.org/10.1016/j.envsci.2016.06.009, 2016.

Artmann, M., Sartison, K., and Vávra, J.: The role of edible cities supporting sustainability transformation - A conceptual multi-dimensional framework tested on a case study in Germany, J. Clean. Prod., 255, 120220 , https://doi.org/10.1016/j.jclepro.2020.120220, 2020.

Ayers, J. and Forsyth, T.: Community-Based Adaptation to Climate Change, Environ. Sci. Policy Sustain. Dev., 51, 22-31, https://doi.org/10.3200/ENV.51.4.22-31, 2009.

Bai, X., van der Leeuw, S., O'Brien, K., Berkhout, F., Biermann, F., Brondizio, E. S., Cudennec, C., Dearing, J., Duraiappah, A., Glaser, M., Revkin, A., Steffen, W., and Syvitski, J.: Plausible and desirable futures in the Anthropocene: A new research agenda, Global Environ. Change, 39, 351-362, https://doi.org/10.1016/j.gloenvcha.2015.09.017, 2016.

Barnett, J. and Campbell, J.: Climate change and small island states: Power, knowledge and the South Pacific, Earthscan/Routledge, London, 2010.

Barnett, J. and O'Neill, S.: Maladaptation, Global Environ. Change, 20, 211-213, https://doi.org/10.1016/j.gloenvcha.2009.11.004, 2010.

Benzie, M., Hedlund, J., and Carlsen, H.: Introducing the Transnational Climate Impacts Index: Indicators of country-level exposure - methodology report, Stockholm Environment Institute, Stockholm, 2016.

Betzold, C.: Adapting to climate change in small island developing states, Climatic Change, 133, 481-489, https://doi.org/10.1007/s10584-015-1408-0, 2015.

Biagini, B., Bierbaum, R., Stults, M., Dobardzic, S., and McNeeley, S. M.: A typology of adaptation actions: A global look at climate adaptation actions financed through the Global Environment Facility, Global Environ. Change, 25, 97-108, https://doi.org/10.1016/j.gloenvcha.2014.01.003, 2014.

Bours, D., McGinn, C., and Pringle, P.: Editors' Notes, New Dir. Eval., 2015, 1-12, https://doi.org/10.1002/ev.20127, 2015.

Boyd, E., James, R. A., Jones, R. G., Young, H. R., and Otto, F. E. L.: A typology of loss and damage perspectives, Nat. Clim. Change, 7, 723-729, https://doi.org/10.1038/nclimate3389, 2017.

Brown, W.: Undoing the Demos. Neoliberalism's Stealth Revolution, MIT Press, Cambridge, Massachusetts, 2015.

Buckley, R.: The contested nature of coastal climate changecommentary to Niven and Bardsley. Planned retreat as a man- 
agement response to coastal risk: A case study from the Fleurieu Peninsula, South Australia, Reg. Environ. Change, 13, 211-214, https://doi.org/10.1007/s10113-012-0383-5, 2013.

Bulkeley, H.: Navigating climate's human geographies: Exploring the whereabouts of climate politics, Dialog. Hum. Geogr., 9, $3-$ 17, https://doi.org/10.1177/2043820619829920, 2019.

Bulkeley, H., Edwards, G. A. S., and Fuller, S.: Contesting climate justice in the city: Examining politics and practice in urban climate change experiments, Global Environ. Change, 25, 31-40, https://doi.org/10.1016/j.gloenvcha.2014.01.009, 2014.

Chatterton, P.: Building transitions to post-capitalist urban commons, Trans. Inst. Brit. Geogr., 41, 403-415, https://doi.org/10.1111/tran.12139, 2016.

Chen, C., Noble, I., Hellmann, J., Coffee, J., Murillo, M., and Chawla, N.: University of Notre Dame Global Adaptation Index: Country Index Technical Report, available at: https://gain. nd.edu/our-work/country-index/ (last access: December 2020), 2015.

Chu, E. and Michael, K.: Recognition in urban climate justice: marginality and exclusion of migrants in Indian cities, Environ. Urban., 31, 139-156, https://doi.org/10.1177/0956247818814449, 2019.

Chu, E., Anguelovski, I., and Carmin, J.: Inclusive approaches to urban climate adaptation planning and implementation in the Global South, Clim. Policy, 16, 372-392, https://doi.org/10.1080/14693062.2015.1019822, 2016.

Corfee-Morlot, J., Cochran, I., Hallegatte, S., and Teasdale, P.J.: Multilevel risk governance and urban adaptation policy, Climatic Change, 104, 169-197, https://doi.org/10.1007/s10584010-9980-9, 2011.

Coulter, L., Serrao-Neumann, S., and Coiacetto, E.: Climate change adaptation narratives: Linking climate knowledge and future thinking, Futures, 111, 57-70, https://doi.org/10.1016/j.futures.2019.05.004, 2019.

Dessai, S. and Hulme, M.: Assessing the robustness of adaptation decisions to climate change uncertainties: A case study on water resources management in the East of England, Global Environ. Change, 17, 59-72, 2007.

Dodman, D. and Satterthwaite, D.: Institutional Capacity, Climate Change Adaptation and the Urban Poor, IDS Bull., 39, 67-74, https://doi.org/10.1111/j.1759-5436.2008.tb00478.x, 2008.

Dow, K., Berkhout, F., Preston, B. L., Klein, R. J. T., Midgley, G., and Shaw, M. R.: Limits to adaptation, Nat. Clim. Change, 3, 305-307, https://doi.org/10.1038/nclimate1847, 2013.

Eckstein, D., Künzel, V., Schäfer, L., and Winges, M.: Global Climate Risk Index 2020: Who suffers most from extreme weather events? Weather-related loss events in 20181999 to 2018, Germanwatch, Bonn, 2020

Eriksen, S. H., Nightingale, A. J., and Eakin, H.: Reframing adaptation: The political nature of climate change adaptation, Global Environ. Change, 35, 523-533, https://doi.org/10.1016/j.gloenvcha.2015.09.014, 2015.

Every, D., Bearman, C., Matthews, R., Reynolds, A., O’Donohue, P., and Clarkson, L.: Contacts versus connectors: The role of Community Fire Safe Group coordinators in achieving positive bushfire safety outcomes, Int. J. Disast. Risk Reduct., 19, 390 398, https://doi.org/10.1016/j.ijdrr.2016.09.012, 2016.

Farbotko, C.: Tuvalu and climate change: Constructions of environmental displacement in the Sydney Morning Herald,
Geogr. Ann. B, 87, 279-293, https://doi.org/10.1111/j.04353684.2005.00199.x, 2005.

Farbotko, C. and McMichael, C.: Voluntary immobility and existential security in a changing climate in the Pacific, Asia Pac. Viewp., 60, 148-162, https://doi.org/10.1111/apv.12231, 2019.

Fekete, A., Damm, M., and Birkmann, J.: Scales as a challenge for vulnerability assessment, Nat. Hazards, 55, 729-747, https://doi.org/10.1007/s11069-009-9445-5, 2010.

Feola, G.: Societal transformation in response to global environmental change: A review of emerging concepts, Ambio, 44, 376390, https://doi.org/10.1007/s13280-014-0582-z, 2015.

Few, R.: Health and climatic hazards: Framing social research on vulnerability, response and adaptation, Global Environ. Change, 17, 281-295, https://doi.org/10.1016/j.gloenvcha.2006.11.001, 2007.

Finn, D. and McCormick, L.: Urban climate change plans: How holistic?, Local Environ., 16, 397-416, https://doi.org/10.1080/13549839.2011.579091, 2011.

Forsyth, T.: Climate justice is not just ice, Geoforum, 54, 230-232, https://doi.org/10.1016/j.geoforum.2012.12.008, 2014.

Fraser, N.: Rethinking recognition, New Left Rev., 3, 107-118, 2000.

Fraser, N.: Recognition without ethics?, Theor. Cul. Soc., 18, $21-$ 42, https://doi.org/10.1177/02632760122051760, 2001.

Fünfgeld, H., Lonsdale, K., and Bosomworth, K.: Beyond the tools: supporting adaptation when organisational resources and capacities are in short supply, Climatic Change, 153, 625-641, https://doi.org/10.1007/s10584-018-2238-7, 2019.

Füssel, H.-M. and Klein, R. J. T.: Climate Change Assessments: An Evolution of Conceptual Thinking, Climatic Change, 75, 301329, https://doi.org/10.1007/s10584-006-0329-3, 2006.

Glover, L. and Granberg, M.: The Politics of Adapting to Climate Change, Palgrave Macmillan/Springer International Publishing, Cham, 2020.

Goldman, M. J., Turner, M. D., and Daly, M.: A critical political ecology of human dimensions of climate change: Epistemology, ontology, and ethics, Wiley Interdisciplin. Rev. Clim. Change, 9, e526, https://doi.org/10.1002/wcc.526, 2018.

Granderson, A. A.: Value conflicts and the politics of risk: challenges in assessing climate change impacts and risk priorities in rural Vanuatu, Clim. Dev., 10, 481-494, https://doi.org/10.1080/17565529.2017.1318743, 2018.

Green Climate Fund: Portfolio dashboard, available at: https: //www.greenclimate.fund/what-we-do/portfolio-dashboard, last access: 24 November 2019.

Grove, K.: On resilience politics: from transformation to subversion, Resilience, 1, 146-153, https://doi.org/10.1080/21693293.2013.804661, 2013.

Head, L.: Cultural ecology: adaptation - retrofitting a concept?, Prog. Hum. Geogr., 34, 234-242, https://doi.org/10.1177/0309132509338978, 2010.

Hickel, J.: The divide: A brief guide to global inequality and its solutions, William Heinemann, London, 2017.

Holland, B.: Procedural justice in local climate adaptation: political capabilities and transformational change, Environ. Polit., 26, 391-412, https://doi.org/10.1080/09644016.2017.1287625, 2017. 
Hughes, S.: Justice in Urban Climate Change Adaptation: Criteria and Application to Delhi, Ecol. Soc., 18, 48, https://doi.org/10.5751/ES-05929-180448, 2013.

Hulme, M.: Why We Disagree About Climate Change: Understanding Controversy, Inaction and Opportunity, Cambridge University Press, Cambridge, 2009.

Huq, S., Roberts, E., and Fenton, A.: Loss and damage, Nat. Clim. Change, 3, 947-949, https://doi.org/10.1038/nclimate2026, 2013.

IPCC: Annex II: Glossary, in: Climate Change 2014: Impacts, Adaptation, and Vulnerability. Part B: Regional Aspects. Contribution of Working Group II to the Fifth Assessment Report of the Intergovernmental Panel on Climate Change, edited by: Barros, V. R., Field, C. B., Dokken, D. J., Mastrandrea, M. D., Mach, K. J., Bilir, T. E., Chatterjee, M., Ebi, K. L., Estrada, Y. O., Genova, R. C., Girma, B., Kissel, E. S., Levy, A. N., MacCracken, S., Mastrandrea, P. R., and White, L. L., Cambridge University Press, Cambridge, UK and New York, NY, USA, 1757-1776, 2014.

Jenkins, K.: Setting energy justice apart from the crowd: Lessons from environmental and climate justice, Energy Res. Soc. Sci., 39, 117-121, https://doi.org/10.1016/j.erss.2017.11.015, 2018.

Juhola, S., Glaas, E., Linnér, B.-O., and Neset, T.-S.: Redefining maladaptation, Environ. Sci. Policy, 55, 135-140, https://doi.org/10.1016/j.envsci.2015.09.014, 2016.

Klein, R. J. T. and Nicholls, R. J.: Assessment of coastal vulnerability to climate change, Ambio, 28, 32-37, 1999.

Klepp, S. and Chavez-Rodriguez, L.: A critical approach to climate change adaptation: discourses, policies, and practices, Routledge, Milton Park, New York, 2018.

Lempert, R. and Schlesinger, M. E.: Climate-change strategy needs to be robust, Nature, 412, 375-375, https://doi.org/10.1038/35086617, 2001.

Lovell, H.: The absences in climate's human geographies, Dialog. Hum. Geogr., 9, 26-28, https://doi.org/10.1177/2043820619829931, 2019.

MacKinnon, D. and Derickson, K. D.: From resilience to resourcefulness: A critique of resilience policy and activism, Prog. Hum. Geogr., 37, 253-270, https://doi.org/10.1177/0309132512454775, 2013.

Magnan, A. K., Schipper, E. L. F., Burkett, M., Bharwani, S., Burton, I., Eriksen, S., Gemenne, F., Schaar, J., and Ziervogel, G.: Addressing the risk of maladaptation to climate change, Wiley Interdisciplin. Rev. Clim. Change, 7, 646-665, https://doi.org/10.1002/wcc.409, 2016.

Malloy, J. T. and Ashcraft, C. M.: A framework for implementing socially just climate adaptation, Climatic Change, 160, 1-14, https://doi.org/10.1007/s10584-020-02705-6, 2020.

McCauley, D. and Heffron, R.: Just transition: Integrating climate, energy and environmental justice, Energy Policy, 119, 1-7, https://doi.org/10.1016/j.enpol.2018.04.014, 2018.

McNamara, K. E., Westoby, R., and Smithers, S. G.: Identification of limits and barriers to climate change adaptation: case study of two islands in Torres Strait, Australia, Geogr. Res., 55, 438-455, https://doi.org/10.1111/1745-5871.12242, 2017.

Mitchell, P. and Borchard, C.: Mainstreaming children's vulnerabilities and capacities into community-based adaptation to enhance impact, Clim. Dev., 6, 372-381, https://doi.org/10.1080/17565529.2014.934775, 2014.
Morchain, D.: Rethinking the framing of climate change adaptation?: Knowledge, power, and politics, in: A Critical Approach to Climate Change Adaptation, edited by: Klepp, S. and ChavezRodriguez, L., Routledge, Abingdon, New York, p. 22, 2018.

Moser, S. C. and Boykoff, M.: Successful adaptation to climate change: linking science and policy in a rapidly changing world, edited by: Moser, S. C. and Boykoff, M. T., Routledge, Milton Park, New York, 2013.

Mycoo, M. A.: Beyond $1.5^{\circ} \mathrm{C}$ : vulnerabilities and adaptation strategies for Caribbean Small Island Developing States, Reg. Environ. Change, 18, 2341-2353, https://doi.org/10.1007/s10113017-1248-8, 2018.

Nalau, J., Preston, B. L., and Maloney, M. C.: Is adaptation a local responsibility?, Environ. Sci. Policy, 48, 89-98, https://doi.org/10.1016/j.envsci.2014.12.011, 2015.

Nightingale, A. J.: Power and politics in climate change adaptation efforts: Struggles over authority and recognition in the context of political instability, Geoforum, 84, 11-20, https://doi.org/10.1016/j.geoforum.2017.05.011, 2017.

Nikolaïdou, S., Klöti, T., Tappert, S., and Drilling, M.: Urban gardening and green space governance: towards new collaborative planning practices, Urban Plan., 1, 5-19, https://doi.org/10.17645/up.v1i1.520, 2016.

Niven, R. J. and Bardsley, D. K.: Planned retreat as a management response to coastal risk: A case study from the Fleurieu Peninsula, South Australia, Reg. Environ. Change, 13, 193-209, https://doi.org/10.1007/s10113-012-0315-4, 2013.

Nussbaum, M.: Capabilities and Social Justice, Int. Stud. Rev., 4, 123-135, https://doi.org/10.1111/1521-9488.00258, 2002.

Nussbaum, M. C.: Creating Capabilities, Harvard University Press, Cambridge, MA, London, UK, 2011.

O'Brien, K.: Global environmental change II: From adaptation to deliberate transformation, Prog. Hum. Geogr., 36, 667-676, https://doi.org/10.1177/0309132511425767, 2012.

O'Brien, K. and Barnett, J.: Global Environmental Change and Human Security, Annu. Rev. Environ. Resour., 38, 373-391, https://doi.org/10.1146/annurev-environ-032112-100655, 2013.

O'Brien, K., Eriksen, S., Nygaard, L. P., and Schjolden, A.: Why different interpretations of vulnerability matter in climate change discourses, Clim. Policy, 7, 73-88, https://doi.org/10.1080/14693062.2007.9685639, 2007.

O'Brien, K. L. and Wolf, J.: A values-based approach to vulnerability and adaptation to climate change, Wiley Interdisciplin. Rev. Clim. Change, 1, 232-242, https://doi.org/10.1002/wcc.30, 2010.

Paavola, J. and Adger, W. N.: Fair adaptation to climate change, Ecol. Econ., 56, 594-609, https://doi.org/10.1016/j.ecolecon.2005.03.015, 2006.

Park, S. E. E., Marshall, N. A. A., Jakku, E., Dowd, A. M. M., Howden, S. M. M., Mendham, E., and Fleming, A.: Informing adaptation responses to climate change through theories of transformation, Global Environ. Change, 22, 115-126, https://doi.org/10.1016/j.gloenvcha.2011.10.003, 2012.

Patterson, J. J., Thaler, T., Hoffmann, M., Hughes, S., Oels, A., Chu, E., Mert, A., Huitema, D., Burch, S., and Jordan, A.: Political feasibility of $1.5^{\circ} \mathrm{C}$ societal transformations: the role of social justice, Curr. Opin. Environ. Sustain., 31, 1-9, https://doi.org/10.1016/j.cosust.2017.11.002, 2018. 
Pelling, M.: Adaptation to climate change: from resilience to transformation, Routledge, Milton Park, New York, 2011.

Pelling, M. and Garschagen, M.: Put equity first in climate adaptation, Nature, 569, 327-329, https://doi.org/10.1038/d41586-01901497-9, 2019.

Pelling, M., Manuel-Navarrete, D., and Redclift, M.: Climate change and the crisis of capitalism: A chance to reclaim self, society and nature, Routledge, London, 2012.

Pelling, M., O'Brien, K., and Matyas, D.: Adaptation and transformation, Climatic Change, 133, 113-127, https://doi.org/10.1007/s10584-014-1303-0, 2014.

Porter, L., Rickards, L., Verlie, B., Moloney, S., Lay, B., Latham, B., Anguelovski, I., Pellow, D., Porter, L., Bosomworth, K., Rickards, L., Verlie, B., Moloney, S., Lay, B., Latham, B., BCNUEJ, I. A., Pellow, D. N., Naarm/Birrarung-ga, Porter, L., Bosomworth, K., Moloney, S., Verlie, B., and Lay, B.: Climate Justice in a Climate Changed World, Plan. Theory Pract., 21, 293 321, https://doi.org/10.1080/14649357.2020.1748959, 2020.

Rawls, J.: A theory of justice, Belknap Press, Cambridge, Massachusetts, 2005 [1971].

Reid, H. and Schipper, E. L. F.: Upscaling community-based adaptation: An introduction to the edited volume, in: CommunityBased Adaptation to Climate Change: Scaling it up, Routledge, Milton Park, 3-21, 2014.

Roberts, E. and Pelling, M.: Loss and damage: an opportunity for transformation?, Clim. Policy, 20, 758-771, https://doi.org/10.1080/14693062.2019.1680336, 2019.

Satterthwaite, D., Huq, S., Reid, H., Pelling, M., and Romero Lankao, P.: Adapting to climate change in urban areas: the possibilities and constraints in low- and middle-income nations, in: Adapting cities to climate change: understanding and addressing the development challenges, edited by: Bicknell, J., Dodman, D., and Satterthwaite, D., Earthscan, London, 3-47, 2009.

Säumel, I., Reddy, S., and Wachtel, T.: Edible City Solutions One Step Further to Foster Social Resilience through Enhanced Socio-Cultural Ecosystem Services in Cities, Sustainability, 11, 972, https://doi.org/10.3390/su11040972, 2019.

Schlosberg, D.: Reconceiving Environmental Justice: Global Movements And Political Theories, Environ. Polit., 13, 517-540, https://doi.org/10.1080/0964401042000229025, 2004.

Schlosberg, D.: Climate Justice and Capabilities: A Framework for Adaptation Policy, Ethics Int. Aff., 26, 445-461, https://doi.org/10.1017/S0892679412000615, 2012.

Schmid, B. and Smith, T. S.: Social transformation and postcapitalist possibility: Emerging dialogues between practice theory and diverse economies, Prog. Hum. Geogr., https://doi.org/10.1177/0309132520905642, in press, 2020.

Sen, A.: The Idea of Justice, Harvard University Press, Cambridge, Massachusetts, 2009.

Shi, L., Chu, E., Anguelovski, I., Aylett, A., Debats, J., Goh, K., Schenk, T., Seto, K. C., Dodman, D., Roberts, D., Roberts, J. T., and VanDeveer, S. D.: Roadmap towards justice in urban climate adaptation research, Nat. Clim. Change, 6, 131-137, https://doi.org/10.1038/nclimate2841, 2016.
Smit, B., Burton, I., Klein, R. J. T., and Wandel, J.: An anatomy of adaptation to climate change and variability, Climatic Change, 45, 223-251, https://doi.org/10.1023/A:1005661622966, 2000.

Sovacool, B. K., Sidortsov, R. V., and Jones, B. R.: Deciphering energy justice and injustice, in Energy Security, Equality, and Justice, Routledge, London, 21-53, 2013.

Spivak, G. C.: Can the Subaltern Speak?, in: Marxism and the Interpretation of Culture, edited by: Nelson, C. and Grossberg, L., Macmillan, London, 271-313, 1988.

Steele, W., Maccallum, D., Byrne, J., and Houston, D.: Planning the Climate-just City, Int. Plan. Stud., 17, 67-83, https://doi.org/10.1080/13563475.2011.638188, 2012.

Steele, W., Mata, L., and Fünfgeld, H.: Urban climate justice: Creating sustainable pathways for humans and other species, Curr. Opin. Environ. Sustain., 14, 121-126, https://doi.org/10.1016/j.cosust.2015.05.004, 2015.

Swyngedouw, E.: Interrogating post-democratization: Reclaiming egalitarian political spaces, Polit. Geogr., 30, 370-380, https://doi.org/10.1016/j.polgeo.2011.08.001, 2011.

Tschakert, P., Tutu, R., and Alcaro, A.: Embodied experiences of environmental and climatic changes in landscapes of everyday life in Ghana, Emotion Space Soc., 7, 13-25, https://doi.org/10.1016/j.emospa.2011.11.001, 2013.

van den Berg, H. J. and Keenan, J. M.: Dynamic vulnerability in the pursuit of just adaptation processes: A Boston case study, Environ. Sci. Policy, 94, 90-100, https://doi.org/10.1016/j.envsci.2018.12.015, 2019.

Walker, G.: Environmental Justice, Routledge, Milton Park, New York, 2012.

Webber, S.: Performative Vulnerability: Climate Change Adaptation Policies and Financing in Kiribati, Environ. Plan. A, 45, 2717-2733, https://doi.org/10.1068/a45311, 2013.

Webber, S.: Climate Change Adaptation as a Growing Development Priority: Towards Critical Adaptation Scholarship, Geogr. Compass, 10, 401-413, https://doi.org/10.1111/gec3.12278, 2016.

Weir, T. and Pittock, J.: Human dimensions of environmental change in small island developing states: some common themes, Reg. Environ. Change, 17, 949-958, https://doi.org/10.1007/s10113-017-1135-3, 2017.

Wilby, R. L. and Dessai, S.: Robust adaptation to climate change, Weather, 65, 180-185, https://doi.org/10.1002/wea.543, 2010.

World Bank: Financial Intermediary Funds: Adaptation Fund, available at: https://fiftrustee.worldbank.org/en/about/unit/dfi/ fiftrustee/fund-detail/adapt\#2, last access: 24 November 2019.

Yuen, E., Jovicich, S. S., and Preston, B. L.: Climate change vulnerability assessments as catalysts for social learning: four case studies in south-eastern Australia, Mitig. Adapt. Strateg. Global Change, 18, 567-590, https://doi.org/10.1007/s11027-012-93764, 2012.

Ziervogel, G., Pelling, M., Cartwright, A., Chu, E., Deshpande, T., Harris, L., Hyams, K., Kaunda, J., Klaus, B., Michael, K., Pasquini, L., Pharoah, R., Rodina, L., Scott, D., and Zweig, P.: Inserting rights and justice into urban resilience: a focus on everyday risk, Environ. Urban., 29, 123-138, https://doi.org/10.1177/0956247816686905, 2017. 